\title{
Sistem Informasi Pembayaran SPP Berbasis WEB pada SMK Muhammadiyah 11 Jakarta Pusat
}

\author{
Rony Wijanarko $^{1^{*}}$, Azizah Shyam Pangestuti ${ }^{2}$ \\ 1,2 Jurusan TEKNIK INFORMATIKA, Fakultas TEKNIK, Universitas Wahid Hasyim \\ Jl. Menoreh Tengah X/22, Sampangan, Semarang 50236. \\ *Email: ronywijanarko@unwahas.ac.id
}

\begin{abstract}
Abstrak
Pemanfaatan Teknologi Informasi dan Komunikasi (TIK) pada bidang pendidikan belum maksimal. Salah satunya yaitu pengelolaan data pembayaran SPP di sebagian sekolah masih menggunakan cara konvensional dan belum terkomputerisasi. Berdasarkan permasalahan yang ada, maka penelitian ini bertujuan untuk mengembangkan sebuah sistem informasi berbasis web yang dapat membantu pengelolaan data pembayaran SPP, serta dapat membantu pengelolaan data pembayaran SPP menjadi lebih baik. Metode penelitian yang digunakan yaitu metode waterfall untuk pengembangannya yang meliputi empat tahap, yaitu analisis, desain, implementasi, dan pengujian. Sistem informasi berbasis web ini dikembangkan menggunakan PHP dan MySQL, serta untuk tampilan antarmuka menggunakan HTML5 dan CSS3 sebagai media mendesain web dan menggabungkan antara layout dengan bahasa pemrograman. Pengujian dilakukan dengan menguji function pada kode yang dibuat dan fungsional dengan menguji link, button dan menu-menu yang ada dan memastikan bahwa semua bagian telah diuji. Hasil dari penelitian ini yaitu sistem informasi pembayaran SPP berbasis dikembangkan dengan menggunakan PHP dan MySQL. Tahap pengembangannya meliputi tahap analisis kebutuhan, tahap desain, tahap implementasi, dan tahap pengujian.
\end{abstract}

Kata kunci: Sistem Informasi Pembayaran SPP, PHP, MySQL, Waterfall

\section{PENDAHULUAN}

\subsection{Latar Belakang}

Perkembangan teknologi dan informasi berjalan begitu cepat dan pesat, seperti perkembangan internet (website), komputer, teknologi telekomunikasi, dan lain-lain. Hal ini dikarenakan kebutuhan akan teknologi dan informasi sangat tinggi untuk membantu berbagai jenis bidang pekerjaan manusia, salah satunya adalah bidang pendidikan. Hal tersebut selaras dengan tantangan pembangunan pendidikan saat ini yaitu dibutuhkan pengembangan kebijakan-kebijakan untuk memperkuat dan memperluas pemanfaatan TIK (Teknologi Informasi dan Komunikasi) di bidang pendidikan.

Dalam dunia pendidikan, khususnya sekolah masih banyak sekali pekerjaan yang dilakukan dengan cara konvensional. Tifatul Sembiring (2010), ketika menjabat sebagai Mentri Komunikasi dan Informatika (Kominfo) pernah mengeluarkan pernyataan bahwa perlu adanya penekanan dalam pemanfaatan Teknologi Informasi dan Komunikasi (TIK) pada bidang pendidikan. Salah satunya adalah pembayaran SPP yang masih menggunakan buku untuk mencatat data pembayaran SPP siswa. SPP merupakan singkatan dari Sumbangan Pembinaan Pendidikan, yaitu dana yang disumbangkan untuk berlangsungnya kegiatan pendidikan di suatu instansi. Pembayaran SPP yang masih dilakukan dengan cara konvensional memiliki kekurangan pada pengelolaan data.

Di SMK Muhammadiyah 11 Jakarta Pusat, pembayaran SPP masih dilakukan dengan cara konvensinal, seperti keterangan yang diberikan oleh Bapak Rahmat, salah satu guru Tata Usaha. Menurut beliau, terdapat beberapa masalah seperti proses pencarian data yang akan memakan banyak waktu dan tenaga apabila data yang ada sudah cukup banyak. Data yang jumlahnya banyak akan terus bertumpuk yang mengakibatkan cukup sulit untuk menyimpannya. Ketika di dalam penyimpanan pun rawan terjadi kerusakan dan kehilangan data. Oleh karena itu, dibutuhkan suatu pengalihan dan perubahan

porses pengelolaan data pembayaran SPP yang dilakukan secara manual menjadi pengelolaan data berbasis komputer. 
Tujuan penulis dalam penelitian ini untuk mempermudah dalam mengelola pembayaran SPP yang dapat menghasilkan perekapan dengan cepat.

Syahbana (2013) melakukan penelitian mengenai Pembangunan Sistem Informasi Administrasi Pembayaran Siswa Madrasah Aliyah Ma'arif Pacitan, menerangkan bahwa sistem memiliki sarana untuk mengelola data siswa, data kelas, dan besar biaya SPP.

Syaifulloh dan Irawan (2017) melakukan penelitian mengenai Perancangan Program Aplikasi Transaksi Pembayaran SPP Pada SMA Negeri 1 Sukoharjo, menerangkan bahwa Aplikasi ini dapat digunakan memasukkan data siswa, data pembayaran, data tanggal pembayaran.

Berdasarkan permasalahan yang ada, penulis mengembangkan sebuah sistem informasi berbasis web yang berjudul "SISTEM INFORMASI PEMBAYARAN SPP BERBASIS WEB PADA SMK MUHAMMADIYAH 11 JAKARTA PUSAT". Dengan adanya sistem tersebut diharapkan dapat membantu pengelolaan data pembayaran SPP menjadi lebih baik.

\section{TINJAUAN PUSTAKA}

\subsection{Sistem Informasi}

Sistem Informasi menurut Jogiyanto $\mathrm{HM}(2005)$ adalah hasil dari pengolahan data dalam suatu bentuk yang lebih berguna dan lebih berarti bagi penerimanya yang menggambarkan suatu kejadian - kejadian (event) yang nyata (fact) yang digunakan untuk pengambilan keputusan.

Sedangkan menurut Brian(O’Brian,2005) system merupakan kombinasi teratur dari orang-orang, perangkat keras (hardware), perangkat lunak (software), jaringan komunikasi, dan sumber daya data yang mengumpulkan, mengubah, dan menyebarkan sebuah informasi dalam sebuah organisasi. (O’Brian,2005)

\subsection{Pengertian Sumbangan Pembinaan Pendidikan (SPP)}

SPP merupakan iuran rutin sekolah yang mana pembayarannya dilakukan setiap sebulan sekali.SPP merupakan salah satu bentuk kewajiban setiap siswa yang masih aktif disekolah tersebut. Dana iuran bulanan tersebut akan dialokasikan oleh sekolah yang bersangkutan untuk membiayai berbagai keperluan atau kebutuhan sekolah supaya kegiatan belajar mengajar disekolah dapat berjalan lancar dengan adanya bantuan dari dana iuran tersebut (Fattah, 2000).

Sistem pembayaran dapat diartikan sebagai salah satu kegiatan atau usaha untuk membantu, melayani, mengarahkan atau mengatur semua kegiatan di dalam mencapai suatu tujuan. Karena pembayaran merupakan unsure terpenting bagi sebuah instansi maka di perlukan suatu sistem yang dapat mengelola sistem pembayaran secara baik.(Mulyadi,2001).

\subsection{Pengujian Black Box}

Pengujian menggunakan sekumpulan aktifitas validasi, dengan pendekatan black box testing. Menurut Shalahuddin dan Rosa (2011), black box testing adalah menguji perangkatan lunak dari segi spesifikasi fungsional tanpa menguji desain dan kode program. Pengujian dimaksudkan untuk mengetahui apakah fungsifungsi, masukan, dan keluaran dari perangkat lunak sesuai dengan spesifikasi yang dibutuhkan. Pengujian kotak hitam dilakukan dengan membuat kasus uji yang bersifat mencoba semua fungsi dengan memakai perangkat lunak apakah sesuai dengan aplikasi yang dibutuhkan.

Menurut Pressman (2010), black box testing juga disebut pengujian tingkah laku, memusat pada kebutuhan fungsional perangkat lunak. Teknik pengujian Black Box memungkinkan memperoleh serangkaian kondisi masukan yang sepenuhnya menggunakan semua persyaratan fungsional untuk suatu program. Beberapa jenis kesalahan yang dapat diidentifikasikan adalah fungsi tidak benar atau hilang, kesalahan antar muka, kesalahan pada struktur data, kesalahan performasi, kesalahan inisialisasi dan akhir program.

\subsection{Metode Waterfall}

Model SDLC air terjun (waterfall) sering juga disebut model sekuensial linier (sequential linear) atau alur hidup klasik (classic life cycle). Model air terjun menyediakan pendekatan alur hidup perangkat lunak secara sekuensial atau terurut dimulai dari analisis, desain, pengodean, pengujian, dan tahap pendukung (support).

Dengan bahasa pemrograman PHP dan HTML database yang digunakan adalah 
MySQL. Diharapkan dengan sistem informasi pembayaran SPP ini dapat membantu pihak sekolahmenjadi lebih efektif dan efisien. Secara garis besar, teknik yang digunakan dalam penerapan metode waterfall. Berikut adalah gambar model air terjun:

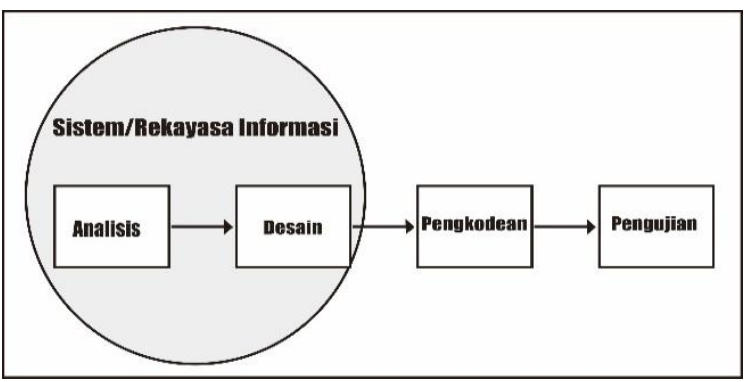

Gambar 1. Metode Waterfall

\subsection{Software Pendukung}

Adapun software pendukung dalam penelitian ini, penulis menggunakan software, hardware, dan brainware untuk mendukung kemudahan dalam pengaplikasiannya, diantaranya:

1. PerangkatLunak (software)

a. Sistem operasi windows

b. MySQL sebagaipengelola database server.

c. PHP dan HTML sebagaibahasapemrograman.

d. XAMPP web server sebagai server lokal dalam pengetesan halaman web.

e. HTML5 dan CSS3 sebagai media mendesain web dan menggabungkan antara layout dengan bahasa pemrograman.

f. Browser sebagai software untuk menjalankan website yang di buat

2. PerangkatKeras (hardware)

a. Komputer dengan spesifikasi : Windows 7 Home32-bit, Processor Intel Core 2 CPU T7500 @2.20GHz,2.00GB RAM.

b. Keyboard dan mouse

3. PerangkatPengguna (brainware)

a. Administrator

b. User

\subsection{Tinjauan Objek}

2.6.1 Sejarah SMK Muhammadiyah 11 Jakarta Pusat

SMK Muhammadiyah 11 Jakarta Pusat berdiri sejak tahun 2004. Terletak dijalan Cempaka Wangi. Sebelumnya sekolah ini merupakan lahan kosong yang dibangun dan telah disepakati untuk dua sekolah SMP 269 dan SMK Muhammadiyah 11, kemudian berkembang menjadi sekolah menengah kejuruan dengan kompetensi keahlian Akutansi dan Administrasi Perkantoran pada saat itu. Semakin berkembangnya teknologi menjadikan tuntutan masyarakat akan kompetensi keahlian berkembang menjadi SMK Muhammadiyah 11 Jakarta Pusat saat ini memiliki 2 jurusan yakni AK dan AP.

\section{METODOLOGI PENELITIAN}

\subsection{Prosedur Pengumpulan Data}

Dalam penelitian lapangan penulis menjelaskan berbagai langkah yang ditempuh dalam menjamin reliabilitas dan validitas data yang diperoleh. Pengumpulan data bertujuan untuk memperoleh informasi yang dibutuhkan untuk penelitian ini. Adapun prosedur yang digunakan yaitu:

\section{a. Prosedure Observasi}

Ditahap ini penulis melakukan pengumpulan data dengan pengamatan dan pencatatan mengenai hal-hal yang diselidiki secara langsung di SMK Muhammadiyah 11 Jakarta yang terletak di Jalan Cempaka Wangi II No.12 Kemayoran Jakarta Pusat.

\section{b. Prosedur Wawancara}

Ditahap ini penulis, penulis mengumpulkan data secara langsung dengan melakukan komunikasi tanya jahwab terhadap pihak sekolah meliputi data guru, data siswa, dan berapa jumlah pembayaran spp per-bulan, untuk melengkapi informasi yang akan digunakan dalam mengembangkan informasi.

\section{c. Prosedur Kepustakaan}

Ditahap ini melakukan pengumpulan data dengan membaca jurnal, media online, dan skripsi terkait pengembangan media informasi sebagai referensi dan landasan teori.

\section{HASIL DAN PEMBAHASAN}

\subsection{Analisis Sistem yang Sedang Berjalan}

Analisis terhadap sistem yang sedang berjalan merupakan salah satu langkah untuk menentukan sistem yang akan dirancang, karena dengan analisa sistem dapat mengetahui kelebihan dan kekurangan dari sistem yang dibuat serta kebutuhan apa saja yang diharapkan dari sistem yang berjalan kemudian dapat dilakukan perbaikan-perbaikan sistem 
tersebut. Selain itu juga pada analisis ini akan mengidentifikasi dan mengevaluasi permasalahan-permasalahan yang terjadi.

Di SMK Muhammadiyah 11 Jakarta Pusat, pembayaran SPP masih dilakukan dengan cara konvensional, seperti keterangan yang diberikan oleh Bapak Rahmat, salah satu guru Tata Usaha. Menurut beliau, terdapat beberapa masalah seperti proses pencarian data yang akan memakan banyak waktu dan tenaga apabila data yang ada sudah cukup banyak. Data yang jumlahnya banyak akan terus bertumpuk yang mengakibatkan cukup sulit untuk menyimpannya. Ketika di dalam penyimpanannya pun rawan terjadi kerusakan dan kehilangan data. Oleh karena itu, dibutuhkan suatu pengalihan dan perubahan proses pengelolaan data pembayaran SPP yang dilakukan secara manual menjadi pengelolaan data berbasis komputer.

\subsection{Use Case}

Use case merupakan pemodelan untuk kelakukan (behavior) sistem yang akan dibuat Secara umum Use Case digunakan untuk mendeskripsikan fungsi apa saja yang ada pada sebuah system. Use Case sistem informasi pembayaran SPP dapat dilihat pada gambar 2.

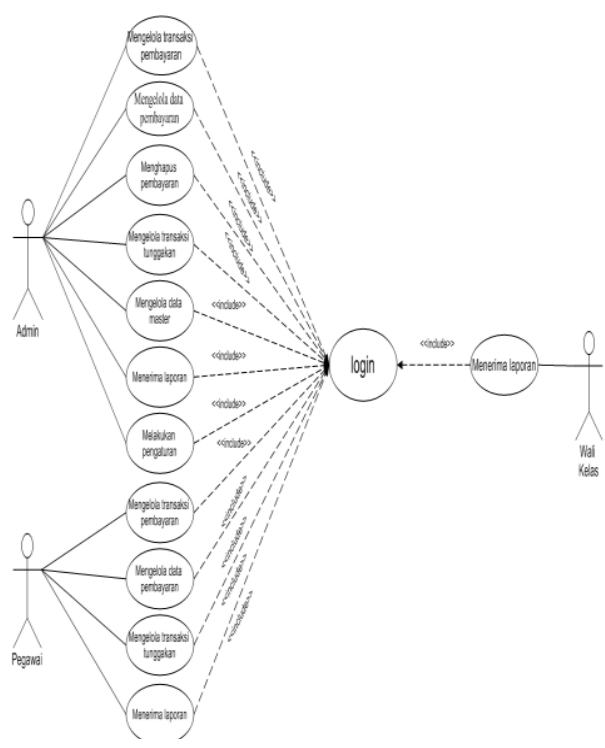

Gambar 2. Usecase Diagram

Gambar 2 ini menjelaskan bahwa admin melakukan login dengan melakukan pengisian username dan password terlebih dahulu dalam sistem pembayaran SPP, Selanjutnya, mengelola transaksi pembayaran sebelum melakukan pembayaran kemudian disusul menginput data siswa yang akan membayar SPP tersebut. Berikutnya ada Pegawai yang juga bisa melakukan transaksi pembayaran SPP yang sebelumnya pegawai juga harus login terlebih dahulu kemudian melakukan transaksi pembayaran yang sama hal nya dengan admin. Dan ada Wali Kelas yang hanya bisa menerima laporan saja dimana wali kelas harus login terlebih dahulu.

\subsection{ERD}

Alur sistem dinyatakan dalam sebuah ERD (Entity Relationship Diagram) seperti yang dapat dilihat pada gambar 3 .

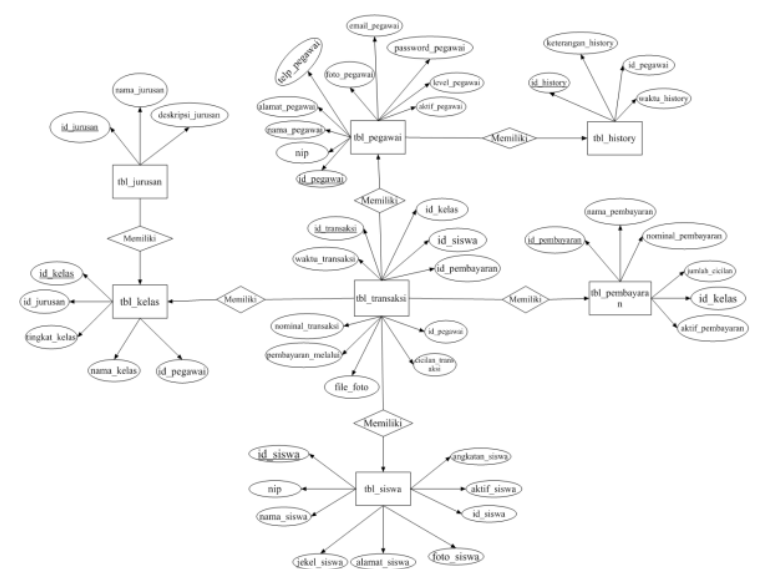

Gambar 3. ERD

Gambar 3 ini menjelaskan bahwa setiap tabel memiliki hubungan antar data dalam basis data, seperti tabel transaksi memiliki tabel pembayaran, tabel siswa, tabel kelas, tabel pegawai. Tabel jurusan memiliki tabel kelas. Tabel pegawai memiliki tabel history. Didalam masing-masing tabel juga berisikan data yang sudah ditentukan.

\subsection{Hasil}

\subsubsection{Halaman WEB Admin}

a. Halaman Login Admin

Username : admin@gmail.com

Password: admin 


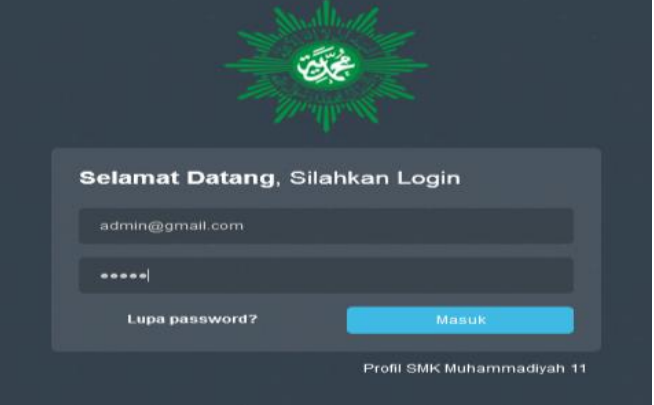

\section{Gambar 4. Halaman login admin}

Pada halaman ini merupakan awal untuk login admin pada sistem. Setelah admin berhasil login, makan akan tampil halaman utama admin, seperti yang ditunjukkan pada gambar 5 .

b. Halaman Utama Admin

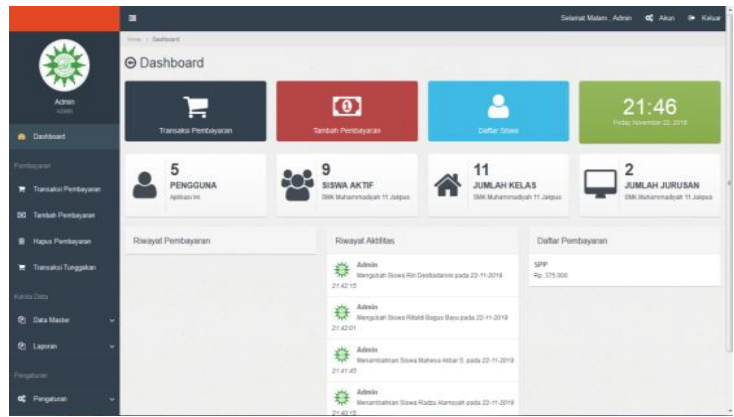

\section{Gambar 5. Halaman utama admin}

Pada halaman ini merupakan tampilan admin pembayaran SPP. Admin bisa mengubah data dan menghapus data, bisa juga melakukan transaksi, seperti yang ditunjukkan paga Gambar 6.

c. Halaman Transaksi Pembayaran

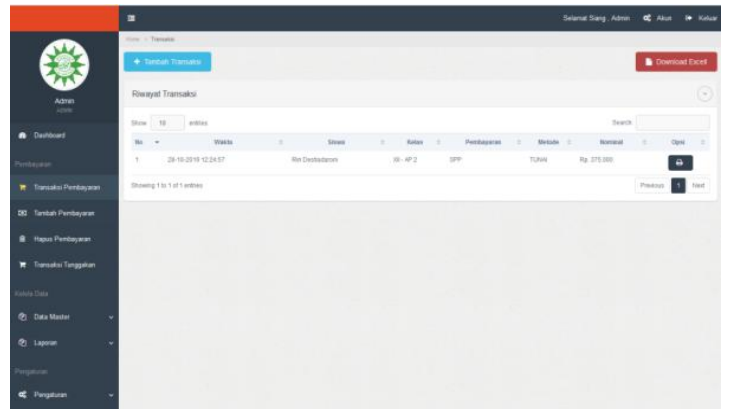

Gambar 6. Halaman transaksi pembayaran

Pada halaman ini admin melakukan transaksi pembayaran SPP. Admin juga bisa melakukan tambah pembayaran seperti yang ditunjukkan pada Gambar 7.

d. Halaman Tambah Pembayaran

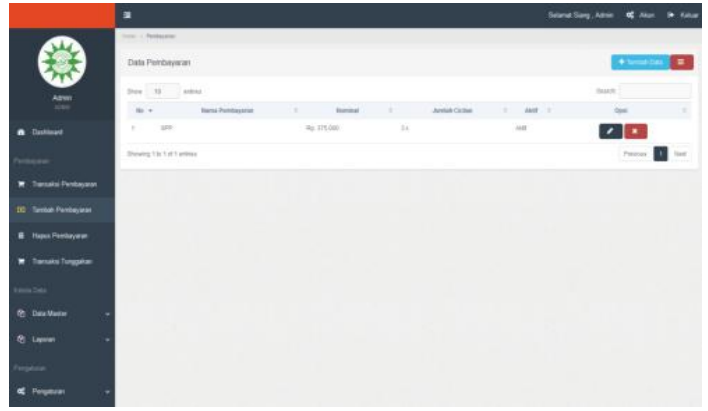

\section{Gambar 7. Halaman tambah pembayaran}

Dihalaman ini admin bisa melakukan tambah data pembayaran seperti jenis pembayaran SPP atau pembayaran lainnya. Admin juga bisa melakukan hapus pembayaran seperti yang ditunjukkan pada Gambar 8 .

e. Halaman Hapus Pembayaran

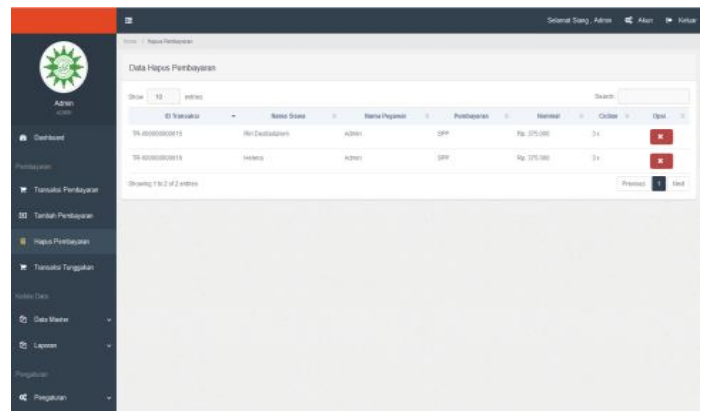

\section{Gambar 8. Halaman hapus pembayaran}

Dihalaman ini admin bisa melakukan menghapus data pembayaran seperti jenis pembayaran SPP atau pembayaran lainnya. Admin juga bisa melakukan transaksi tunggakan seperti yang ditunjukkan pada Gambar 9. 
f. Halaman Transaksi Tunggakan

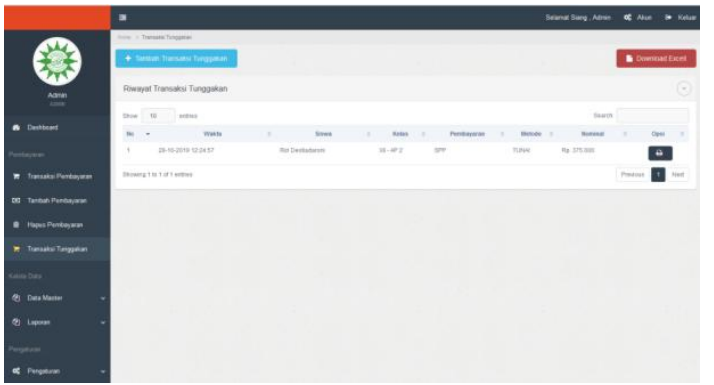

\section{Gambar 9. Halaman transaksi tunggakan}

Dihalaman ini admin bisa melakukan data transaksi tunggakan pembayaran SPP. Admin juga menyimpan data siswa seperti yang ditunjukkan pada Gambar 10.

\section{g. Halaman Siswa}

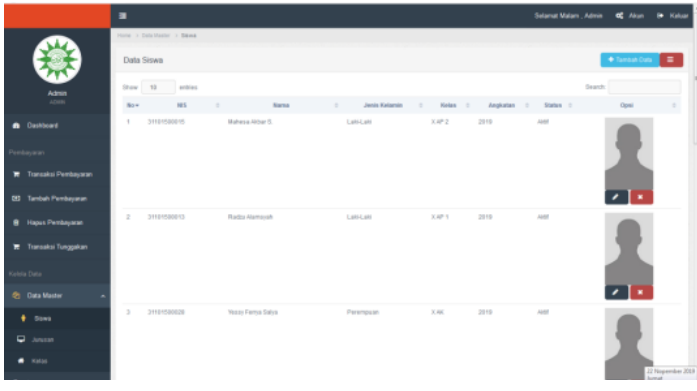

Gambar 10. Halaman data siswa

Dihalaman ini admin bisa melakukan tambah data, ubah data maupun menghapus data setiap siswa. Admin juga menyimpan data jurusan seperti yang ditunjukkan pada Gambar 11.

h. Halaman Jurusan

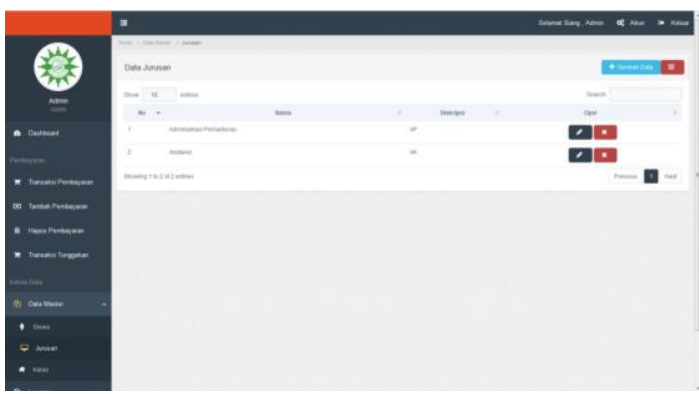

Gambar 11. Halaman data jurusan
Dihalaman ini admin bisa melakukan tambah data, ubah data maupun menghapus data setiap jurusan yang ada di sekolah. Admin juga menyimpan data kelas seperti yang ditunjukkan pada Gambar 12.

i. Halaman Kelas

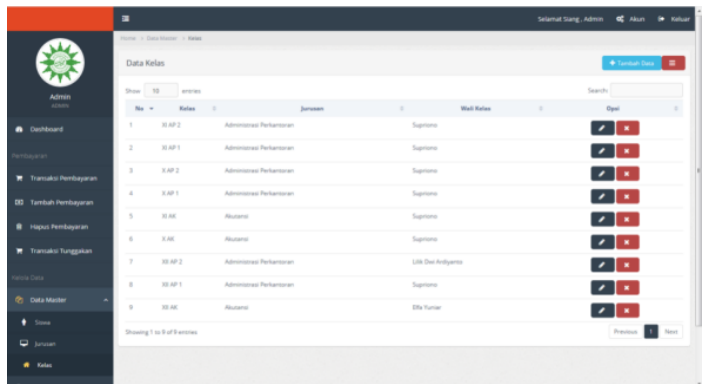

\section{Gambar 12. Halaman data kelas}

Dihalaman ini admin bisa melakukan tambah data, ubah data maupun menghapus data setiap nama kelas. Admin juga menyimpan laporan jenis pembayaran seperti yang ditunjukkan pada Gambar 13.

j. Halaman Laporan Jenis Pembayaran

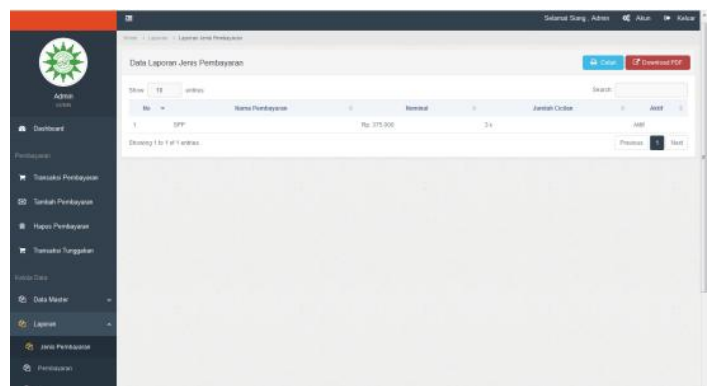

\section{Gambar 13. Halaman laporan jenis pembayaran}

Dihalaman ini admin bisa menerima laporan data jenis pembayaran. Admin juga menyimpan laporan data pembayaran seperti yang ditunjukkan pada Gambar 14. 
k. Halaman Pembayaran

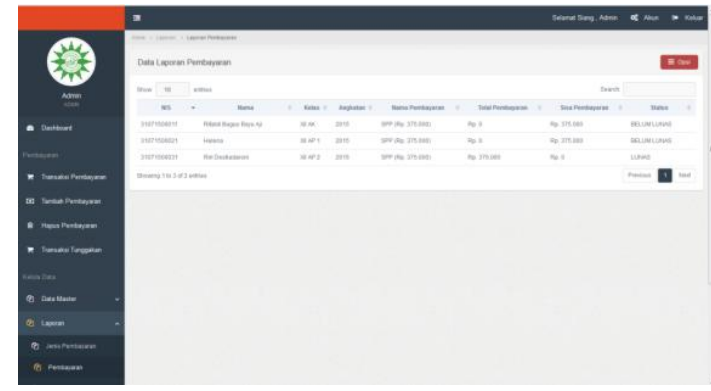

Gambar 14. Data pembayaran siswa

Dihalaman ini admin bisa menerima laporan data pembayaran siswa. Admin juga menyimpan laporan data siswa seperti yang ditunjukkan pada Gambar 15.

1. Halaman Laporan Siswa

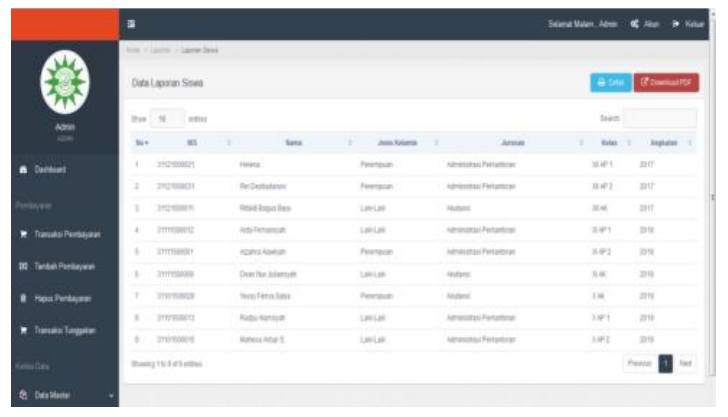

\section{Gambar 15. Halaman laporan data siswa}

Dihalaman ini admin bisa menerima data laporan nama siswa yang ada di sistem pembayaran SPP. Admin juga menyimpan laporan jurusan seperti yang ditunjukkan pada Gambar 16.

m. Halaman Laporan Jurusan

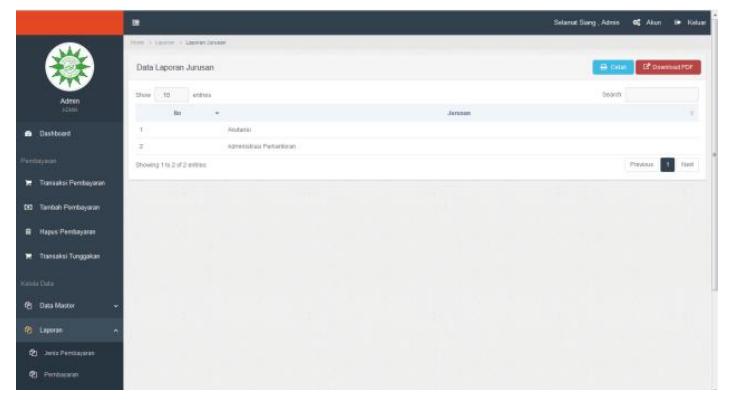

Gambar 16. Halaman laporan data jurusan

Dihalaman ini admin bisa menerima data laporan nama jurusan yang ada di sistem pembayaran SPP. Admin juga menyimpan laporan kelas seperti yang ditunjukkan pada Gambar 17.

n. Halaman Laporan Kelas

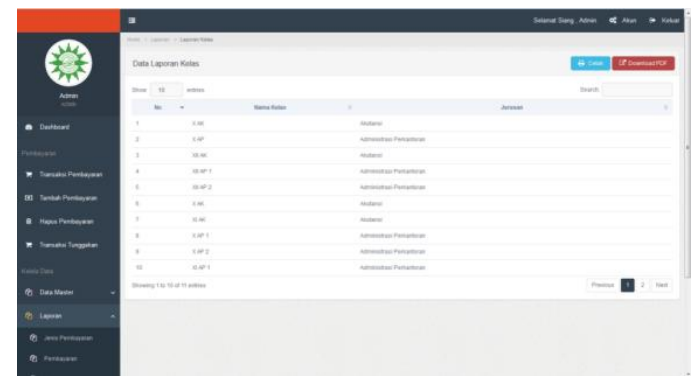

\section{Gambar 17. Halaman laporan data kelas}

Dihalaman ini admin bisa menerima data laporan nama kelas yang ada di sistem pembayaran SPP. Admin juga menyimpan laporan pengguna seperti yang ditunjukkan pada Gambar 18.

o. Halaman Laporan Pengguna

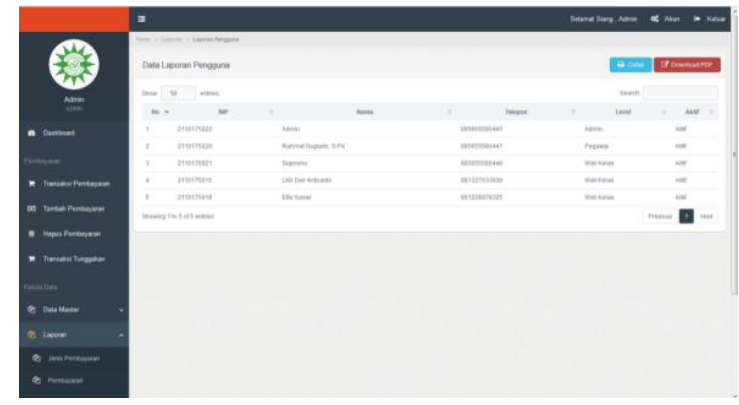

\section{Gambar 18. Halaman laporan pengguna}

Dihalaman ini admin bisa menerima data laporan siapa saja mengakses sistem pembayaran SPP. Admin juga merubah akun pengguna seperti yang ditunjukkan pada Gambar 19.

p. Halaman Pengaturan Pengguna

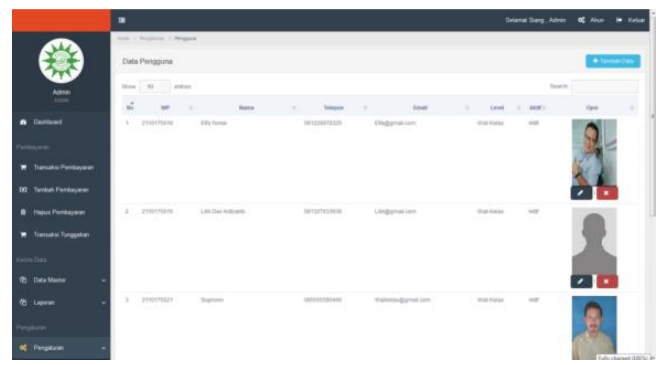

Gambar 19. Halaman pengaturan pengguna 
Dihalaman ini admin bisa menambah, mengedit, dan menghapus data pengguna pada sistem. Admin juga merubah akun admin sendiri seperti yang ditunjukkan pada Gambar 20.

q. Halaman Pengaturan Akun

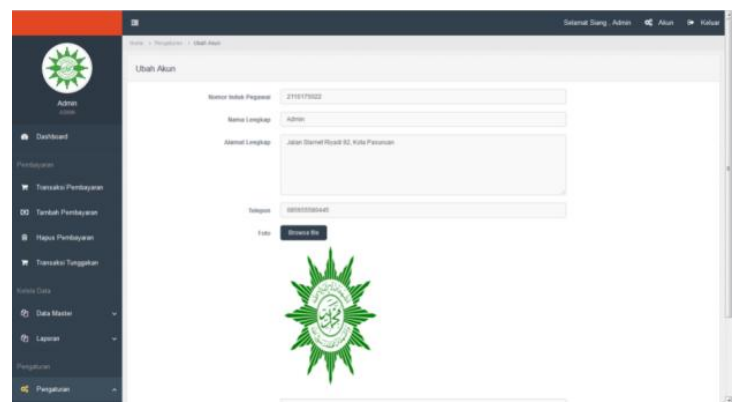

Gambar 20. Halaman pengaturan akun

Pada halaman ini admin bisa mengedit atau merubah data admin pada sistem. Selain Admin, Pegawai juga bisa login ke system.

\section{KESIMPULAN DAN SARAN \\ 5.1. Kesimpulan}

Kesimpulan yang dapat penulis ambil berdasarkan hasil dan pembahasan yang telah diuraikan pada bab sebelumnya sebagai berikut:

1) Sistem informasi iniberhasil dibangun untuk mempermudah proses pembayaran spp yang dilakukan secara online, mempermudah dalam pengolahan data dan mempermudah $T U$ dan Siswa untuk bertransaksi pembayaran spp lebih cepat.

2) Sistem informasi ini berhasil dibangun untuk membantu pihak sekolah khususnya dalam pencetakan laporan yang tidak lagi memerlukan pencatatan dalam bentuk arsip.

\subsection{Saran}

Saran yang dapat penulis berikan berdasarkan hasil dan pembahasan yang telah diuraikan diatas sebagai berikut:

1) Sistem pembayaran SPP perlu dilakukan backup untuk menjaga dari segala sesuatu yang tidak diinginkan. Misalnya, komputer mengalami kerusakan.

2) Dalam penelitian berikutnya diharapkan ada penambahan beberapa fitur untuk melengkapi sistem pembayaran SPP, yaitu penambahan SMS Gateway untukmemberitahukan keterlambatan pembayaran siswa, dan wali murid akan mendapatkan SMS pemberitahuan keterlambatan pembayaran.

\section{DAFTAR PUSTAKA}

Fattah, Nanang, Dr. , 2000, Manajemen

Berbasis Sekolah, Strategi Pemberdayaan

Sekolah dalam rangka Peningkatan Mutu dan Kemandirian Sekolah, Andira, Bandung. Departemen Pendidikan dan Kebudayaan .

Jogiyanto H.M, 2005, Analisis dan Disain Sistem Informasi, Andi,. Yogyakarta

Mulyadi, 2001. Sistem Akuntansi, edisi ketiga. Jakarta : Salemba Empat.

O'Brian, James.A. 2005. Introduction to Information System. McGraw-Hill. New York.

Pressman, R.S. 2010. Rekayasa Perangkat Lunak. Yogyakarta: Andi

Shalahuddin, Rosa. 2014. Rekayasa Perangkat Lunak Berorientasi Objek. Bandung : Informatika.

Syahbana Ali, 2013,Pembangunan Sistem Administrasi Pembayaran Siswa Madrasah Aliyah Ma'arif Pacitan, Jurnal Speed-sentra Penelitian Engineering dan Edukasi Vol 5, No 3, ISSN: 1979-9330.

Syaifulloh Ahmad, Irawan Dedi, 2013, Perancangan Program Aplikasi Transaksi Pembayaran SPP Pada SMA Negri 1 Sukoharjo. 